\title{
Comparison of biomass burning tracer concentrations between two winter seasons in Krynica Zdrój
}

\author{
Katarzyna Janoszka ${ }^{1}$ [D $\cdot$ Marianna Czaplicka ${ }^{1} \cdot$ Krzysztof Klejnowski $^{1}$ \\ Received: 29 November 2019 / Accepted: 5 February 2020/Published online: 15 February 2020 \\ (C) The Author(s) 2020
}

\begin{abstract}
Biomass burning is one source of air pollution that emits soot, smoke, particulate matter, free radicals and other substances, affecting human health, air quality, cloud formation processes and climate change. During biomass burning, organic biomass burning tracers are emitted, such as levoglucosan and its isomers mannosan and galactosan, which are formed at temperatures above $300{ }^{\circ} \mathrm{C}$ during cellulose and hemicellulose pyrolysis. The objective of this research is the measurement of biomass burning tracer concentrations in $\mathrm{PM}_{10}$ samples in Krynica during two winter seasons from 01.12.2017 to 31.03.2018 and from 01.12.2018 to 26.03.2019. The average concentrations of organic carbon were $9.48 \mu \mathrm{g} / \mathrm{m}^{3}$ in the $2017 / 2018$ season and $8.79 \mu \mathrm{g} / \mathrm{m}^{3}$ in the $2018 / 2019$ season. The average concentration of levoglucosan in the $\mathrm{PM}_{10}$ samples in $2017 / 2018$ was $137 \mathrm{ng} / \mathrm{m}^{3}$, while in 2018/2019, the average concentration reached $245 \mathrm{ng} / \mathrm{m}^{3}$. Levoglucosan was the dominant compound among the determined biomass burning tracers, accounting for $88.6 \%$ in $2017 / 2018$ and $72.4 \%$ in $2018 / 2019$. The conducted measurements show that the levoglucosan to mannosan ratio was equal to 10.5 and 3.9 in 2017/2018 and 2018/2019, respectively. The biomass smoke organic carbon was approximately $10.6 \%$ in $2017 / 2018$ and $20.5 \%$ in $2018 / 2019$. These results correspond to the contribution of biomass smoke to organic carbon, which was equal to $14.4 \%$ and $28.4 \%$ in the $2017 / 2018$ and 2018/2019 seasons, respectively.
\end{abstract}

Keywords Biomass burning · Tracers · Levoglucosan · Mannosan · Galactosan

\section{Introduction}

Biomass burning is a global phenomenon resulting from forest fires and slashes and the burning of forests for agricultural, agricultural waste burning and residential uses. Biomasses, such as straw; wood in the form of pellets; granules or sawdust; and waste, such as scales, can be used as fuel during direct combustion or co-firing. Biomass burning (BB) is a source of air pollution that emits particulate matter, free radicals and other substances, which affect human health, air quality, cloud formation processes and climate change (Schkolnik and Rudich, 2006). In recent years, several organic molecular markers have been widely used in terms of monitoring environmental pollution with biomass burning. During biomass burning, organic biomass burning tracers are emitted, such

Katarzyna Janoszka

katarzyna.janoszka@ipis.zabrze.pl

1 Institute of Environmental Engineering Polish Academy of Science, 34 M. Skłodowskiej-Curie St, 41-819 Zabrze, Poland as levoglucosan (LG) and its isomers mannosan (MN) and galactosan (GA), which form at temperatures above $300{ }^{\circ} \mathrm{C}$ during cellulose and hemicellulose pyrolysis. These three tracers are most suitable and recognized due to their high abundance and relatively long stability under specific environmental conditions (Fabbri et al. 2009; Zhang et al. 2010; Simoneit et al. 1999; Simoneit 2002). As levoglucosan is the most abundant among all mentioned biomass burning tracers (Schmidl et al. 2008; Simoneit et al. 1999), the relative abundance of LG to MN and GA in atmospheric particulate matter (PM) is affected by the type of biomass burnt (Fabbri et al. 2009; Schmidl et al. 2008). The LG/MN ratio is higher than 50 for a poor quality brown coal, while for softwood and hardwood/grass combustion, it is approximately 5 and 10 20 , respectively. The number of grasses is approximately 25 (Fabbri et al. 2009; Schmidl et al. 2008), and the burning of rice straw is 26.6 (Engling et al. 2009). The LG/MN ratio can be used to distinguish wood type burnt, but it makes it difficult to separate emissions from hardwood and crop residual burning (Cheng et al. 2013). The concentration of biomass burning tracers can be determined by different techniques, but the most popular techniques are gas chromatography with mass 
spectrometry (GC/MS) and high-performance liquid chromatography with pulsed amperometric detection (HPLC/PAD) (Schkolnik and Rudich 2006; Janoszka and Czaplicka 2019). In this research, the concentration of biomass burning tracers was determined by GC/MS.

In Poland, the levels of biomass burning tracers are poorly documented. Consequently, the European Union has funded research on air quality to determine biomass burning tracer concentrations. To address this shortcoming, this report focuses on the following objectives: (i) determination of the level of biomass burning tracer concentrations in $\mathrm{PM}_{10}$ samples from the health resort Krynica during two winter seasons, 2017/ 2018 and 2018/2019; (ii) determination of individual biomass burning tracer percentages from the total sum of tracers in $\mathrm{PM}_{10}$; (iii) determination of $\mathrm{LG} / \mathrm{MN}$ and $\mathrm{LG} /(\mathrm{MN}+\mathrm{GA})$ ratios; and (iv) estimation of organic carbon contribution from biomass burning in the total OC.

\section{Materials and methods}

Samples of $\mathrm{PM}_{10}$ were collected over a 24-h cycle on $47 \mathrm{~mm}$ Whatman QMA quartz filters at the measurement station Krynica (health resort $\varphi=49^{\circ} 24^{\prime} 28^{\prime \prime}, h=20^{\circ} 57^{\prime} 39^{\prime \prime}, h=$ $582 \mathrm{~m}$ above sea level) from 01.12.2017 to 31.03.2018 (118 samples) and from 01.12.2018 to 26.03.2019 (112 samples). Samples were collected in accordance with the methodology described previously (Klejnowski et al. 2017) with the use of a low flow sampler with separating head $\mathrm{PM}_{10}$ Atmoservice PNS3D15/LVS3d, with a stabilized flow of $2.3 \mathrm{~m}^{3} / \mathrm{h}$. Blank samples were checked before every month ( 8 in total).

The concentrations of biomass burning tracers were determined based on the method described by Poore (2002). Levoglucosan, mannosan and galactosan were determined by placing a sample of $\mathrm{PM}_{10}$ collected on a quartz filter (one half of the 47-mm filter) in a 4-ml dark glass vial. The following were added to the sample: $2 \mathrm{ml}$ of pyridine $(\mathrm{POCH})$ as a solvent and $50 \mu \mathrm{l}$ of a mixture of N,O-bis(trimethylsilyl)trifluoro-acetamide and trimethylchlorosilane (BSTFA: TMCS, 99: 1, Supelco) as a derivatizing agent. The vial was shaken for $1 \mathrm{~min}$ after closure and placed in an oven at $40{ }^{\circ} \mathrm{C}$ for $30 \mathrm{~min}$. The extracts $(1 \mathrm{ml})$ were analysed after filtration through a syringe filter $(0.22 \mu \mathrm{m})$ using a Shimadzu GC-2010 gas chromatograph coupled with a mass spectrometry detector equipped with an HP-5MS column (30 m, $0.25 \mathrm{~mm}$, and $0.25 \mu \mathrm{m}$ ). The limit of detection (LOD) was equal to $0.25 \mathrm{ng} / \mathrm{m}^{3}$ for LG, $0.11 \mathrm{ng} / \mathrm{m}^{3}$ for $\mathrm{MN}$ and $0.12 \mathrm{ng} /$ $\mathrm{m}^{3}$ for GA. The limit of quantification (LOQ) was equal to 0.76 , 0.34 and $0.35 \mathrm{ng} / \mathrm{m}^{3}$ for LG, MN and GA, respectively. Method precision expressed as a relative standard deviation was equal to $19 \%$, and recovery was $95 \%$. Pure levoglucosan was purchased from Sigma-Aldrich, Germany. Mannosan and galactosan were obtained from LGC, Germany. The validation parameters are presented in Table 1.

The analysis of organic carbon (OC) was performed with the use of a thermal-optical organic and elemental carbon analyser, Sunset Laboratory Inc., using the EUSAAR_2 protocol, which was developed as a proposed standard method for European measurement stations under the European Supersites for Atmospheric Aerosol Research project (EUSAAR project, CEN/TR 16243, 2011). For each real sample batch/series, the blank samples were analysed to verify the presence of OC. Based on the results of the $1.0 \mathrm{~cm}^{2}$ pieces from the 25 blank samples, the LOQ was calculated as $0.94 \mu \mathrm{gC} /$ $\mathrm{cm}^{2}$ for OC. Repeatability was estimated from 25 independent measurements of the same sample under the same measuring conditions (slice of quartz filter with a glucose standard solution of concentration $4 \mu \mathrm{gC} /$ $\mu \mathrm{L})$. Repeatability determined that the relative standard deviation for OC was $1.6 \%$.

\section{Results and discussion}

The mass concentrations of the analysed chemical species, biomass burning tracers, $\mathrm{PM}_{10}$ and $\mathrm{OC}$ for health resort Krynica are summarized in Tables 2 and 3 and Figs. 1, 2 and 3.

The average mass concentration of $\mathrm{PM}_{10}$ was $28.4 \mu \mathrm{g} / \mathrm{m}^{3}$ in the $2017 / 2018$ season and $24.6 \mu \mathrm{g} / \mathrm{m}^{3}$ in the $2018 / 2019$ season. These results correspond to the results from Gothenburg and Umeå with a $\mathrm{PM}_{10}$ concentration of $21 \mu \mathrm{g} /$ $\mathrm{m}^{3}$ (Ferm and Sjöberg 2015) and a regional background of approximately $20 \mu \mathrm{g} / \mathrm{m}^{3}$, as determined by Forsberg et al. (2005) in Sweden, e.g., Trelleborg and Malmö. A similar annual average of $24.5 \mu \mathrm{g} / \mathrm{m}^{3}$ was reported by Monteiro et al. (2018) in Porto. The results are higher than those of Riccione, Italy, with a concentration of $8 \mu \mathrm{g} / \mathrm{m}^{3}$ (Vassura et al. 2014), but lower than those of Cracov and Brzezina, Poland, with a mean value of approximately $100 \mu \mathrm{g} / \mathrm{m}^{3}$ (Samek et al. 2013).
Table 1 Validation parameters for levoglucosan, mannosan and galactosan

\begin{tabular}{lllll}
\hline Biomass burning tracers & LOD ng $/ \mathrm{m}^{3}$ & LOQ $\mathrm{ng} / \mathrm{m}^{3}$ & Calibration lines & Regression coeff. \\
\hline LG & 0.25 & 0.76 & $y=87,429 \mathrm{x}-44,445$ & 0.999 \\
MN & 0.11 & 0.34 & $y=76,601 \mathrm{x}-52,178$ & 0.998 \\
GA & 0.12 & 0.35 & $y=189,952 \mathrm{x}-81,840$ & 0.997 \\
\hline
\end{tabular}


Table 2 Average, minimum and maximum concentrations of biomass burning tracers $\left(\mathrm{ng} / \mathrm{m}^{3}\right), \mathrm{PM}_{10}\left(\mu \mathrm{g} / \mathrm{m}^{3}\right)$ and $\mathrm{OC}\left(\mu \mathrm{g} / \mathrm{m}^{3}\right)$ in aerosols in the two winter campaigns

\begin{tabular}{lcccccccc}
\hline & $2017 / 2018$ & \multicolumn{6}{l}{$2018 / 2019$} \\
\cline { 2 - 3 } \cline { 7 - 8 } & Average (SD) & Min. & Max. & & Average (SD) & Min. & Max. \\
\hline LG & $137(178)$ & 0.6 & 972 & & $245(250)$ & 21.0 & 1520 \\
MN & $13.0(19.5)$ & 0.8 & 99.8 & $62.1(39.9)$ & 7.9 & 226 \\
GA & $4.7(14.4)$ & 0.2 & 80.9 & $31.1(20.5)$ & 0.5 & 95.2 \\
PM $_{10}$ & $28.4(16.6)$ & 6.71 & 106 & & $24.6(15.7)$ & 4.98 & 77.9 \\
OC & $9.48(5.93)$ & 2.43 & 36.5 & $8.79(6.72)$ & 1.54 & 33.6 \\
\hline
\end{tabular}

The average temperature during the winter season in 2017/ 2018 was $-2.2{ }^{\circ} \mathrm{C}$, and in the season $2018 / 2019$, it was $1.4^{\circ} \mathrm{C}$.

The mean biomass burning tracer concentrations from Krynica in the two winter seasons of 2017/2018 and 2018/ 2019 were 155 and $338 \mathrm{ng} / \mathrm{m}^{3}$, respectively. The average concentrations of the three biomass burning tracers in Europe are very diverse, e.g., $379 \mathrm{ng} / \mathrm{m}^{3}$ in rural backgrounds in Seiffen, Germany (Iinuma et al. 2009); $506 \mathrm{ng} / \mathrm{m}^{3}$ and $562 \mathrm{ng} / \mathrm{m}^{3}$ in urban backgrounds in Ghent, Belgium (Pashynska et al. 2002; Zdráhal et al. 2002); and $772 \mathrm{ng} / \mathrm{m}^{3}$ in winter in suburban sites in Elverum, Norway (Yttri et al. 2007). In Brno and Šlapanice, the average concentrations of tracers in winter in $\mathrm{PM}_{1}$ were 273 and $646 \mathrm{ng} / \mathrm{m}^{3}$, respectively (Křůmal et al. 2015).

For $\mathrm{PM}_{10}$ biomass burning, tracer concentrations in Krynica in 2017/2018 were $137 \mathrm{ng} / \mathrm{m}^{3}$ (from 0.6 to $972 \mathrm{ng}$ / $\mathrm{m}^{3}$ ) for $\mathrm{LG}, 13.0 \mathrm{ng} / \mathrm{m}^{3}$ (from 0.8 to $99.8 \mathrm{ng} / \mathrm{m}^{3}$ ) for $\mathrm{MN}$ and $4.7 \mathrm{ng} / \mathrm{m}^{3}$ (from 0.2 to $80.9 \mathrm{ng} / \mathrm{m}^{3}$ ) for GA. In the 2018/2019 season in Krynica, the tracer concentrations were higher, reaching $250 \mathrm{ng} / \mathrm{m}^{3}$ (from 21.0 to $1520 \mathrm{ng} / \mathrm{m}^{3}$ ), $62.1 \mathrm{ng} / \mathrm{m}^{3}$ (from 7.9 to $226 \mathrm{ng} / \mathrm{m}^{3}$ ) and $31.1 \mathrm{ng} / \mathrm{m}^{3}$ (from 0.5 to $95.2 \mathrm{ng}$ / $\mathrm{m}^{3}$ ) for LG, MN and GA, respectively. These results are comparable with biomass burning tracers determined in Ghent (urban), Belgium, where the concentration of LG was $477 \mathrm{ng} / \mathrm{m}^{3}$ (from 121 to $1133 \mathrm{ng} / \mathrm{m}^{3}$ ), that of MN was $65.9 \mathrm{ng} / \mathrm{m}^{3}$ (from 17.3 to $153 \mathrm{ng} / \mathrm{m}^{3}$ ) and that of GA reached $19.6 \mathrm{ng} / \mathrm{m}^{3}$ (from 4.4 to $44.2 \mathrm{ng} / \mathrm{m}^{3}$ ) (Zdráhal et al. 2002). In the work of Pashynska et al. (2002), the concentrations of

Table 3 Percentages of biomass burning tracers in the total sum of compounds in atmospheric aerosols, and the LG/MN and LG/(MN+ GA) ratios in the two winter seasons of 2017/2018 and 2018/2019

\begin{tabular}{lll}
\hline Biomass burning tracers & $2017 / 2018$ & $2018 / 2019$ \\
\hline LG & 88.6 & 72.4 \\
MN & 8.4 & 18.4 \\
GA & 3.0 & 9.2 \\
LG/MN & 10.5 & 3.9 \\
LG/(MN GA) & 7.7 & 2.6 \\
\hline
\end{tabular}

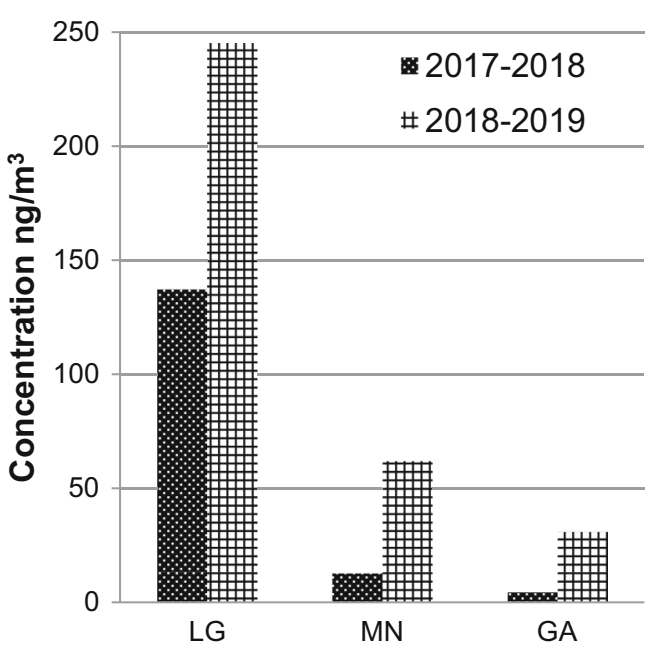

Fig. 1 The average concentrations of biomass burning tracers in 2017/ 2018 (black with dots) and 2018/2019 (chequered pattern)

biomass burning tracers were $420 \mathrm{ng} / \mathrm{m}^{3}$ (from 96 to $1900 \mathrm{ng} / \mathrm{m}^{3}$ ) for levoglucosan, $61 \mathrm{ng} / \mathrm{m}^{3}$ (from 10 to $290 \mathrm{ng} /$ $\mathrm{m}^{3}$ ) for mannosan and $25 \mathrm{ng} / \mathrm{m}^{3}$ (from 4.9 to $115 \mathrm{ng} / \mathrm{m}^{3}$ ) for galactosan. Higher results were observed in Porto, with a winter mean of LG equal to $774 \mathrm{ng} / \mathrm{m}^{3}$ (Monteiro et al. 2018) and Elverum (suburban) winter means of 605,167 and $4.0 \mathrm{ng} / \mathrm{m}^{3}$ for LG, MN and GA, respectively (Yttri et al. 2007). Biomass consists of several main components, such as cellulose with 40-50\% dry weight of wood; hemicellulose with 20-30\% dry weight of wood; and lignins, combined with tannins, terpenes and other substances. The relative amount of tracers is determined by the type of biomass (softwood, hardwood, and grass) (Simoneit 2002, Janoszka and Czaplicka 2019) and the proportions of the components (Pereira et al. 2017).

The differences between the results in the 2017/2018 and $2018 / 2019$ seasons may have been caused by various temperatures. The correlation between the levoglucosan concentration and temperature for the 2017/2018 and 2018/2019 seasons is presented in Figs. 1 and 2, respectively. In the 2017/ 2018 season, the mean temperature was $-2.2^{\circ} \mathrm{C}$, including 8 days from 25.02 .2018 to 04.03 .2018 where temperatures were under $-10{ }^{\circ} \mathrm{C}$. However, the maximum peaks in the biomass burning tracers may result from local conditions such as wind direction and humidity together with temperature. In the $2018 / 2019$ season, the mean temperature was $-1.4{ }^{\circ} \mathrm{C}$, and there were only 5 days with temperatures under $-10^{\circ} \mathrm{C}$. From 19.01.2019 to 24.01.2018, the temperature was approximately $-10^{\circ} \mathrm{C}$, which correlates with the peak biomass burning tracers. This difference could be caused by people who used coal and other types of biomass, such as straw or miscanthus pellets, instead of wood in domestic heating more in 2017/2018 than in 2018/2019.

Table 3 shows the percentage of individual tracers in the total sum of determined compounds based on average values. Among the determined biomass burning tracers, LG is the 
Fig. 2 Variations in average levoglucosan concentrations and temperatures during the winter season of 2017/2018

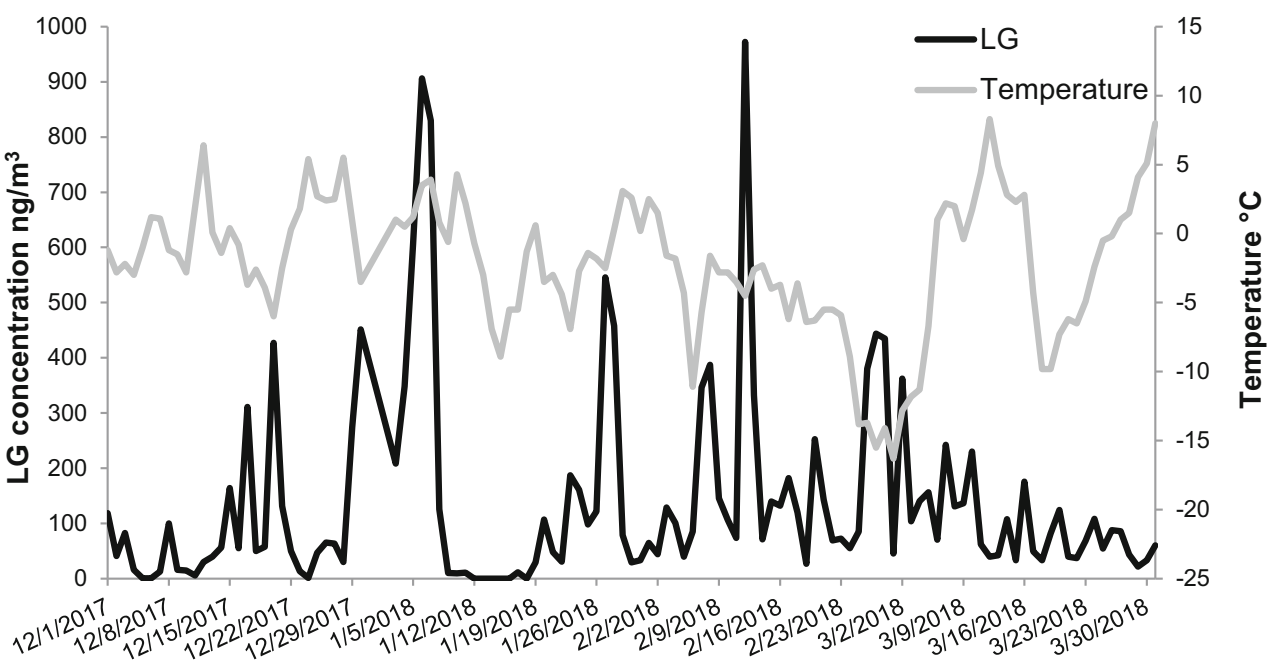

most dominant. The levoglucosan percentage in the total biomass burning tracer sum was $88.6 \%$ in the $2017 / 2018$ season and $72.4 \%$ in the $2018 / 2019$ season. The mannosan percentages were $8.4 \%$ and $18.4 \%$ in the $2017 / 2018$ and $2018 / 2019$ seasons, respectively. The least abundant was galactosan, with percentages of $3.0 \%$ in the $2017 / 2018$ season and $9.2 \%$ in 2018/2019. Zdráhal et al. (2002) observed a similar correlation with an LG percentage of $84.9 \%$, MN of $11.8 \%$ and GA of $3.3 \%$. The same relationship was observed for $\mathrm{PM}_{1}$ in Brno and Šlapanice in the Czech Republic, with $80 \%$ LG, $13 \% \mathrm{MN}$ and $7 \%$ of GA when breaking down total amount of tracers (Kř̆umal et al. 2015).

To distinguish smoke emissions from different fuel types, relative abundances may be used: levoglucosan to mannosan (LG/MN) and levoglucosan to the sum of mannosan and galactosan (LG/(MN+GA)). In Krynica Zdrój, the mean LG/ $\mathrm{MN}$ ratio for the $2017 / 2018$ season was 10.5 , and that for the $2018 / 2019$ season $2018 / 2019$ was 3.9. The mean LG/(MN+ GA) values were 7.7 and 2.6 for the $2017 / 2018$ and 2018/ 2019 seasons, respectively. The results may indicate that in the $2017 / 2018$ season in Krynica, a co-combustion of hardwood and straw or miscanthus pellets with coal occurred, and in the 2018/2019 season, softwood burning was dominant. A similar result for the $\mathrm{LG} / \mathrm{MN}$ ratio in the 2018/2019 season was reported by Cordell et al. (2016) for Leicester; GB ranged from 2.6 to 4.6 , and the $\mathrm{LG} /(\mathrm{MN}+\mathrm{GA})$ ratio ranged from 2.1 to 3.0, which is typical for softwood. For Lille, France, the LG/MN ratio varies from 2.8 to 6.7 , and the $\mathrm{LG} /(\mathrm{MN}+\mathrm{GA})$ ratio varies from 2.0 to 4.3 , possibly indicating a higher hardwood contribution. However, the results of the LG/MN ratio from standard reference material on urban aerosols in Washington, USA and Prague, Czech Republic were equal to 9.4 and 4.9, respectively, suggesting that of the mixture of hardwood and softwood input into the Washington samples and Prague samples, softwood was predominant (Louchouarn et al. 2009). Caseiro and Oliveira (2012) reported the winter average LG/MN ratio in Birmingham, GB, with an urban background of 7 for fine fraction $\mathrm{PM}_{2.5}$ and 18 for core fraction $\mathrm{PM}_{2.5-10}$. The ratio in Okinawa varies from 12.3 to 13.9 in winter, suggesting hardwood, softwood and
Fig. 3 Variations in average levoglucosan concentration and temperature during the winter season of 2018/2019

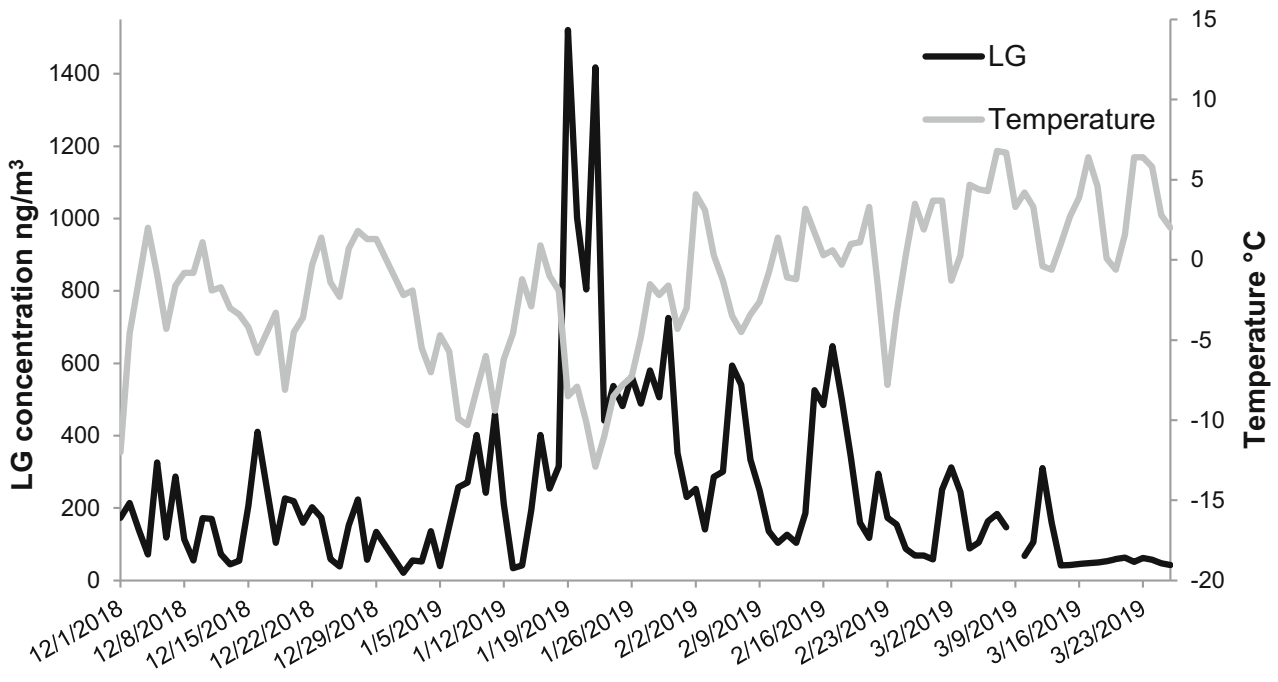


hardwood mixtures or softwood and plant straw mixture burning (Zhu et al. 2015). In the 2017/2018 season in Krynica, the $\mathrm{LG} / \mathrm{MN}$ ratio was higher compared to the data in the literature, which may be the result of different biomass burnings other than softwood and hardwood, such as straw or miscanthus pellets with coal. Because the atmospheric aerosol samples contain a spectrum of particulate matter, the observed biomass burning ratios must be considered carefully.

The amount of organic carbon derived from the burning of biomass can be calculated from Equation (1), which was proposed by Puxbaum et al. (2007) and Gelencsér et al. (2007), where an emission factor of 7.35 was based on the OC/LG mass emission ratio:

Biomass smoke $\mathrm{OC}=$ levoglucosan $\times 7.35$

The data are presented in Table 4.

In the winter season of $2017 / 2018$, the OC equalled $9480 \mathrm{ng} / \mathrm{m}^{3}$, and in the season of $2018 / 2019$, it was $8790 \mathrm{ng} / \mathrm{m}^{3}$. These results are comparable to those obtained by Zhang et al. (2010) from Guangzhou in China, where the OC concentration was $7930 \mathrm{ng} / \mathrm{m}^{3}$. In $\mathrm{PM}_{1}$, the OC contents in Brno and Šlapanice in the winter season of 2009 were 4.73 and $6.00 \mu \mathrm{g} / \mathrm{m}^{3}$, respectively, and in winter 2010 , they were 9.97 and $8.74 \mu \mathrm{g} / \mathrm{m}^{3}$, respectively (Křmul et al. 2015). The biomass smoke OC values calculated by Equation (1) were equal to $1010 \mathrm{ng} / \mathrm{m}^{3}$ and $1800 \mathrm{ng} / \mathrm{m}^{3}$ in the seasons of 2017/2018 and 2018/2019, respectively. The results are different from those reported by Puxbaum et al. (2007) in winter at several sites, such as $48 \mathrm{ng} / \mathrm{m}^{3}$ in Azores; $134 \mathrm{ng} / \mathrm{m}^{3}$ in Puy de Dôme, France; $7739 \mathrm{ng} / \mathrm{m}^{3}$ in Aveiro, Portugal; and $4800 \mathrm{ng} / \mathrm{m}^{3}$ in K-Puszta, Hungary. However, the results from Krynica are comparable with those presented by Caseiro and Oliveira (2012) in Oporto in the winter season, with a roadside value of $1.5 \mu \mathrm{g} / \mathrm{m}^{3}$ and an urban background value of $1.1 \mu \mathrm{g} / \mathrm{m}^{3}$. The biomass smoke OC according to Equation (1) was $10.6 \%$ of organic carbon measured in the $2017 / 2018$ season and $20.5 \%$ of that measured in the 2018/2019 season.

The LG concentration was also used to calculate the contribution of biomass burning to OC by Equation (2), as proposed by Sang et al. (2011):

Table 4 Concentration of biomass smoke OC and the OC levels in two winter seasons (2017/2018 and 2018/2019), $\mathrm{ng} / \mathrm{m}^{3}$

\begin{tabular}{lcrrrr}
\hline $\mathrm{ng} / \mathrm{m}^{3}$ & $2017 / 2018$ & & \multicolumn{2}{l}{$2018 / 2019$} & \\
\cline { 2 - 3 } & \multicolumn{2}{c}{ Biomass smoke OC } & OC & & \multicolumn{2}{l}{ Biomass smoke OC } & OC \\
\hline Average & 1010 & 9480 & 1800 & 8790 \\
Maximum & 7150 & 36,500 & 11,200 & 33,800 \\
Minimum & 4.0 & 2430 & 154 & 1540 \\
\hline
\end{tabular}

BB to OC $=\frac{\frac{\text { Levoglucosan-17.5 }}{1000 \cdot \mathrm{OC}}}{0.082} \cdot 100 \%$

The contributions of biomass smoke to $\mathrm{OC}$ in Krynica, according to Equation (2), in the winters of $2017 / 2018$ and $2018 / 2019$ were $14.4 \%$ and $28.4 \%$, respectively. These results are compatible with the data obtained by Sang et al. (2011) from Hot Tsiu, China, with contributions in the range of 6.5 to $11 \%$, and Zhang et al. (2008) from Beijing, with contributions ranging from 14 to $32 \%$ in $\mathrm{PM}_{10}$ aerosols. However, the results from Krynica are lower than those reported by Caseiro et al. (2009), whereas those from Vienna range from 31.3 to $39.5 \%$, those from Graz range from 38.4 to $58.9 \%$, and those from Salzburg range from 34.4 to $70.2 \%$. For Brno and Slapanice in the winter of 2009, the relative contributions of biomass smoke to $\mathrm{OC}$ were 34.2 and $51.7 \%$, respectively, and 24.1 and $20.2 \%$ in the winter of 2010, respectively (Křumal et al. 2015).

\section{Conclusions}

The obtained results showed the following:

1. The average biomass burning tracer concentration in the winter season of 2017/2018 was lower than that in the winter season of 2018/2019.

2. Levoglucosan, the most abundant tracer, accounted for $88.6 \%$ of the total determined biomass burning tracers in the $2017 / 2018$ season, while in the $2018 / 2019$ season, it accounted for $72.4 \%$.

3. Galactosan, the least abundant tracer, comprised $3.0 \%$ of the sum of tracers in 2017/2018 and 9.2\% in 2018/2019.

4. The LG/MN ratios were 10.5 and 3.9 for $2017 / 2018$ and $2018 / 2019$, respectively, while the $\mathrm{LG} /(\mathrm{MN}+\mathrm{GA})$ ratios were 7.7 and 2.6 for 2017/2018 and 2018/2019, respectively. In the 2017/2018 season in Krynica, the co-firing of hardwood and straw or the co-firing of miscanthus pellets with coal was dominant, and in the 2018/2019 season, softwood burning was dominant.

5. The biomass smoke OC calculated according to Puxbaum et al. (2007) and Gelencsér et al. (2007) was equal to $1010 \mathrm{ng} / \mathrm{m}^{3}$ in the $2017 / 2018$ season and $1800 \mathrm{ng} / \mathrm{m}^{3}$ in the $2018 / 2019$ season, which is $10.6 \%$ of the organic carbon measured in the $2017 / 2018$ season and $20.5 \%$ of the organic carbon measured in the $2018 / 2019$ season. However, the results of the contribution of biomass smoke to OC according to Sang et al. (2011) were $14.4 \%$ and $28.4 \%$ in the $2017 / 2018$ and 2018/2019 seasons, respectively. 
Acknowledgements The authors thank Dr. Barbara Mathews for performing the $\mathrm{OC}$ analysis.

Author' contributions Katarzyna Janoszka performed the experiments and co-wrote the paper; Marianna Czaplicka analysed the data and cowrote the paper; Krzysztof Klejnowski collected the samples.

Funding information This research was funded by the Institute of Environmental Engineering of the Polish Academy of Sciences basic (statutory) research project no. 1a-119/2019: "Temporal and spatial variabilities in atmospheric aerosol chemical compositions as a tool for evaluating the effects of implementing air protection programmes in Poland".

\section{Compliance with ethical standards}

Conflict of interest The authors declare that they have no conflicts of interest.

Open Access This article is licensed under a Creative Commons Attribution 4.0 International License, which permits use, sharing, adaptation, distribution and reproduction in any medium or format, as long as you give appropriate credit to the original author(s) and the source, provide a link to the Creative Commons licence, and indicate if changes were made. The images or other third party material in this article are included in the article's Creative Commons licence, unless indicated otherwise in a credit line to the material. If material is not included in the article's Creative Commons licence and your intended use is not permitted by statutory regulation or exceeds the permitted use, you will need to obtain permission directly from the copyright holder. To view a copy of this licence, visit http://creativecommons.org/licenses/by/4.0/.

\section{References}

Caseiro A, Bauer H, Schmidl C, Pio CA, Puxbaum H (2009) Wood burning impact on $\mathrm{PM}_{10}$ in three Austrian regions. Atmos Environ 43:2186-2195

Caseiro A, Oliveira C (2012) Variation in wood burning organic marker concentrations in the atmospheres of four European cities. J Environ Monit 14:2261-2269

Cheng Y, Engling G, He KB, Duan FK, Ma YL, Du ZY, Liu JM, Zheng M, Weber RJ (2013) Biomass burning contribution to Beijing aerosol. Atmos Chem Phys Discuss 13:8387-8434

Cordell RL, Mazet M, Dechoux C, Hama SML, Staelens J, Hofman J, Stroobants C, Roekens E, Kos GPA, Weijers EP, Frumau KFA, Panteliadis P, Delaunay T, Wyche KP, Monks PS (2016) Evaluation of biomass burning across North West Europe and its impact on air quality. Atmos Environ 141:276-286

Engling G, Lee JJ, Tsai Y-W, Lung S-CC, Chou CC-K, Chan C-Y (2009) Size-resolved anhydrosugar composition in smoke aerosol from controlled field burning of rice straw. Aerosol Sci Technol 43: 662-672

Fabbri D, Torri C, Simoneit BRT, Marynowski L, Rushdi AI, Fabiańska MJ (2009) Levoglucosan and other cellulose and lignin markers in emissions from burning of Miocene lignites. Atmos Environ 43: 2286-2295

Ferm M, Sjöberg K (2015) Concentration and emission factors for $\mathrm{PM}_{2.5}$ and $\mathrm{PM}_{10}$ from road traffic in Sweden. Atmos Environ 119:211-219

Forsberg B, Hansson H-C, Johansson C, Areskoug H, Persson K, Järvholm B (2005) Comparative health impact assessment of local and regional particulate air pollutants in Scandinavia. Ambio 31(1): $11-19$
Gelencsér A, May B, Simpson D, Sánchez-Ochoa A, Kasper-Giebl A, Puxbaum H, Caseiro A, Pio C, Legrand M (2007) Source apportionment of PM2.5 organic aerosol over Europe: primary/secondary, natural/anthropogenic, and fossil/biogenic origin. J Geophys Res 112:1-12

Iinuma Y, Engling G, Puxbaum H, Herrmann H (2009) A highly resolved anion-exchange chromatographic method for determination of saccharidic tracers for biomass combustion and primary bioparticles in atmospheric aerosol. Atmos Environ 43:1367-1371

Janoszka K, Czaplicka M (2019) Methods for the determination of levoglucosan and other sugar anhydrides as biomass burning tracers in environmental samples-a review. J Sep Sci 42:319-329

Klejnowski K, Janoszka K, Czaplicka M (2017) Characterization and seasonal variation of organic and elemental carbon and levoglucosan in $\mathrm{PM}_{10}$ in Krynica Zdroj. Poland Atmos 8(190):1-13

Křumal K, Mikuška P, Večeřa Z (2015) Monosaccharide anhydrides, monocarboxylic acids and OC/EC in PM1 aerosols in urban areas in the Czech Republic. Atmos Pol Res 6:917-927

Louchouarn P, Kuo LJ, Wade TL, Schantz M (2009) Determination of levoglucosan and its isomers in size fractions of aerosol standard reference materials. Atmos Environ 43:5630-5636

Monteiro A, Gouveia S, Scotto M, Sorte S, Gama C, Gianelle VL, Colombi C, Alves C (2018) Investigating PM10 episodes using levoglucosan as tracer. Air Qual Atmos Health 11:61-68

Pashynska V, Vermaylen R, Vas G, Maenhaut W, Claeys M (2002) Development of a gas chromatographic/ion trap mass spectrometric method for the determination of levoglucosan and saccharidic compounds in atmospheric aerosols. Application to urban aerosols. J Mass Spectrom 37:1249-1257

Pereira GM, De Oliveira AN, Caumo SES, Soares S, Teinilä K, Custódio D, Hillamo R, Alves C, Vasconcellos (2017) Chemical composition of aerosol in São Paulo, Brazil: influence of the transport of pollutants. Air Qual Atmos Health 10:457-468

Poore MW (2002) Levoglucosan in $\mathrm{PM}_{2.5}$ at the Fresno Supersite. J Air Waste Manage Assoc 52:3-4

Puxbaum H, Caseiro A, Sánches-Ochoa A, Kasper-Gielb A, Claeys M, Gelencsér A, Legrand M, Preunkert S, Pio C (2007) Levoglucosan levels at background sites in Europe for assessing the impact of biomass combustion on the European aerosol background. J Geophys Res 112:1-11

Samek L, Zwoździak A, Sówka I (2013) Chemical characterization and source identification of particulate matter $\mathrm{PM}_{10}$ in a rural and urban site in Poland. Environ Prot Eng 39:91-103

Sang X-F, Chan C-Y, Engling G, Chan L-Y, Wang X-M, Zhang Y-N, Shi S, Zhang Z-S, Zhang T (2011) Levoglucosan enhancement in ambient aerosol during springtime transport events of biomass burning smoke to Southeast China. Tellus 63B:129-139

Schkolnik G, Rudich Y (2006) Detection and quantification of levoglucosan in atmospheric aerosol: a review. Anal Bioanal Chem 385:26-33

Schmidl C, Marr IL, Caseiro A, Kotianová P, Berner A, Bauer H, KasperGiebl A, Puxbaum H (2008) Chemical characterization of fine particle emissions from wood stove combustion of common woods grooving in mid-European Alpine regions. Atmos Environ 42: 126-141

Simoneit BRT (2002) Biomass burning - a review of organic tracers for smoke from incomplete combustion. Appl Geochem 17:129-162

Simoneit BRT, Schauer JJ, Nolte CG, Oros DR, Elias VO, Fraser MP, Rogge WF, Cass GR (1999) Levoglucosan, a tracer for cellulose in biomass burning and atmospheric particles. Atmos Environ 33:173182

Technical report, ref. no. CEN/TR 16243:2011

Vassura I, Venturini E, Marchetti S, Piazzalunga A, Bernardi E, Fermo P, Passarini F (2014) Markers and influence of open biomass burning on atmospheric particulate size and composition during a major bonfire event. Atmos Environ 82:218-225 
Yttri KE, Dye C, Kiss G (2007) Ambient aerosol concentrations of sugar and sugar-alcohols at four different sites in Norway. Atmos Chem Phys 7:4267-4279

Zdráhal Z, Oliveira J, Vermaylen D, Claeys M, Maenhaut W (2002) Improved method for quantifying levoglucosan and related monosaccharide anhydrides in atmospheric aerosols and application to samples from urban and tropical locations. Environ Sci Technol 36:747-753

Zhang T, Claeys M, Cachier H, Dong S, Wang W, Maenhaut W, Liu X (2008) Identification and estimation of the biomass burning contribution to Beijing aerosol using levoglucosan as a molecular marker. Atmos Environ 42:7013-7021
Zhang Z, Engling G, Lin C-Y, Chou CC-K, Lung S-C, Chang S-Y, Fan S, Chan C-Y, Zhang Y-H (2010) Chemical speciation, transport and contribution of biomass burning smoke to ambient aerosol in Guangzhou, a mega city of China. Atmos Environ 44:3187-3195

Zhu C, Kawamura K, Kunwar B (2015) Effect of biomass burning over the western North Pacific Rim: wintertime maxima of anhydrosugars in ambient aerosols in Okinawa. Atmos Chem Phys 15:1959-1973

Publisher's note Springer Nature remains neutral with regard to jurisdictional claims in published maps and institutional affiliations. 